\title{
Science literacy empowerment for elementary school students at Kera Island Kupang Regency-East Nusa Tenggara
}

\author{
U. Uslan ${ }^{a, 1, *}$, Abdul Syahril Muh ${ }^{b, 2}$, Julhidayat Muhsam ${ }^{b, 3}$, Ummu Aiman ${ }^{b, 4}$, Dian Meilani, ${ }^{b, 5}$, Muhammad R \\ Letasado $^{\mathrm{b}, 6}$, Suryadin Hasyda ${ }^{\mathrm{b}, 7}$, Rizqy Amelia Ramadhaniyah Ahmad ${ }^{\mathrm{b}, 8}$. \\ ${ }^{a}$ Department of Elementary School Teacher, Universitas Muhammadiyah Kupang, Jl.K.H. Ahmad Dahlan No.17, Kupang 85111, Indonesia

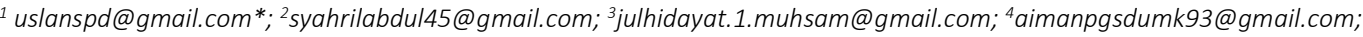 \\ ${ }^{5}$ dianmeilani99@gmail.com; ${ }^{6}$ adymaper12@gmail.com; ${ }^{7}$ suryadinhasyda92@gmail.com; ${ }^{8}$ rizqy.ahmad92@gmail.com \\ * Corresponding author
}

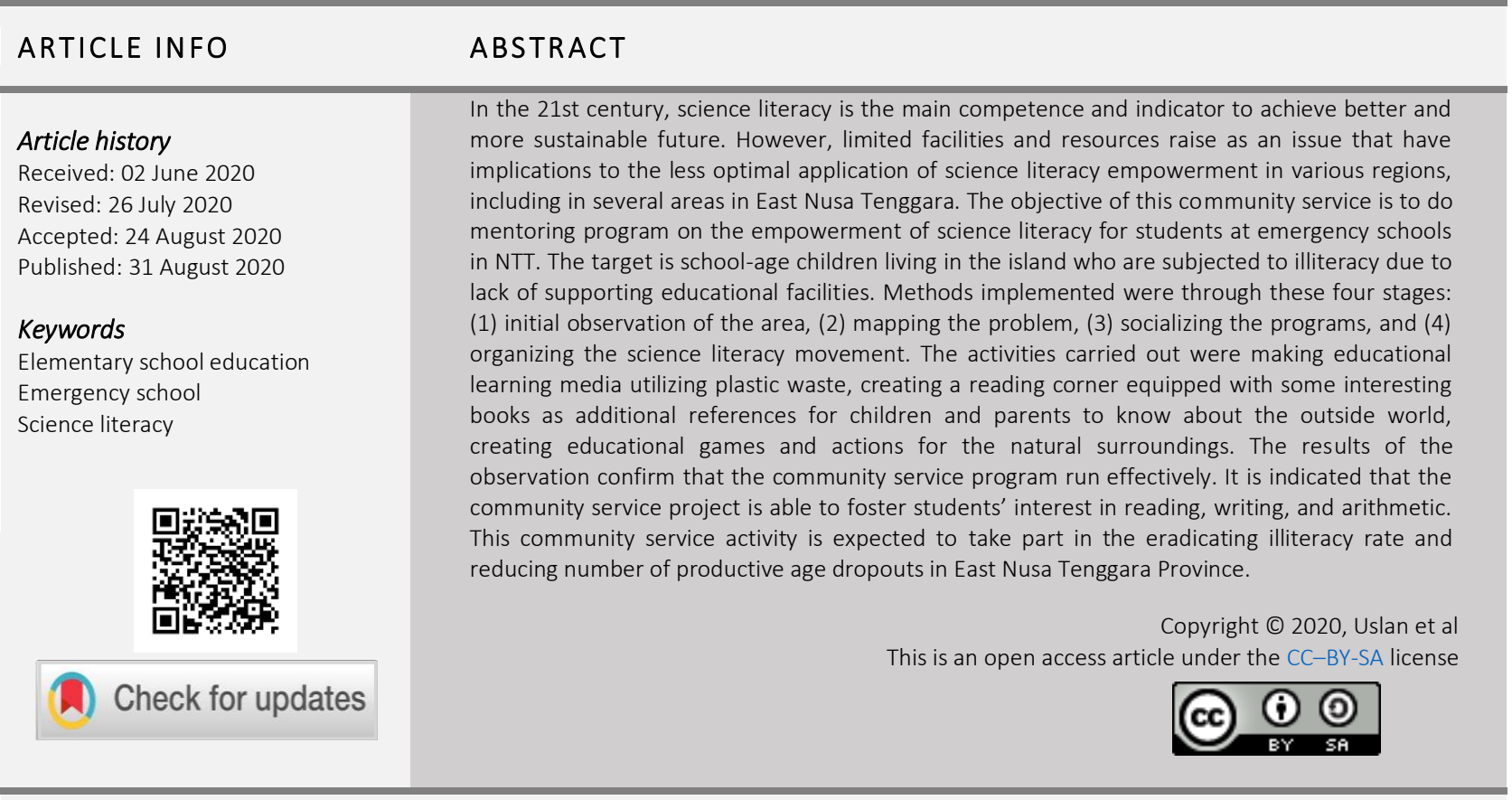

How to cite: Uslan, U., Muh, A., Muhsam, J., Aiman, U., Meilani, D., Letasado, M., Hasyda, S., \& Ahmad, R. (2020). Science literacy empowe rment for elementary school students at Kera Island Kupang Regency-East Nusa Tenggara. Journal of Community Service and Empowerment, 1(2), 86-92. doi: https://doi.org/10.22219/jcse.v1i2.12364

\section{PENDAHULUAN}

Perkembangan ilmu pengetahuan dan teknologi (IPTEK) suatu negara akan menentukan daya saing setiap negara (Çalışkan, 2015; Şener \& Saridoğan, 2011). Perkembangan IPTEK juga akan berimplikasi pada dunia pendidikan, baik dari segi struktur kurikulum, tujuan pendidikan, hingga penyelenggaraan pendidikan (Christy \& Duane, 2013; Kaur, 2013). Penyelenggaraan pendidikan diarahkan untuk mencetak lulusan yang memiliki keterampilan berpikir (Jeronen, Palmberg, \& Yli-Panula, 2016; Lin, 2011; Scott, 2015) serta memiliki literasi yang baik (Bybee, R., \& McCrae, 2011; Mashfufah, Nurkamto, Sajidan, \& Wiranto, 2018; Palani, 2012). Harapannya, dengan keterampilan berpikir dan literasi yang mumpuni, masyarakat akan mampu berkompetisi di era globalisasi. Semakin baik keterampilan berpikir dan dan semakin luas literasi masyarakatnya, semakin tinggi peluang suatu negara bertahan di kancah persaingan dunia internasional.

Kita mengetahui bahwa literasi adalah kunci untuk membuat dunia kita lebih berkelanjutan (Marope, 2017), damai, dan aman secara finansial (GPE Secretariat, 2019). Sehubungan dengan itu, dalam Sustainable Development Goals (SDGs) tertuang salah satu tujuan, yaitu tercapainya pemerataan pendidikan (Purnama \& Apriliani, 2018), selain bidang-bidang lain seperti pertanian (Budiyanto \& Hadi, 2020) lingkungan (Nurwidodo, Amin, Ibrohim, \& Sueb, 2020), dan kesehatan (Suswati \& Maulida, 2020). Secara keseluruhan, SDGs memberikan 'resep' bagi negara-negara untuk menjadi produktif dan sejahtera, menghasilkan populasi yang berpendidikan dan dilengkapi dengan baik untuk pekerjaan di abad ke-21. 
Beberapa tantangan tentang data Sustainable Development Goal 4 (SDG 4) tentang pendidikan yang berkualitas dan pembelajaran seumur hidup untuk semua. SDG 4 indikator 4.4.1, khususnya, telah menekankan pentingnya keterampilan teknologi informasi dan komunikasi. Namun yang terpenting, kita harus bisa membaca, menulis, dan kalkulasi dasar (Montoya, 2018). Berbagai penelitian telah menunjukkan bahwa ketika seseorang menerima pendidikan yang berkualitas, mereka memiliki lebih banyak kesempatan dalam hidup, seperti kesehatan yang lebih baik, kesempatan kerja yang lebih besar, dan partisipasi yang meningkat dalam proses politik. Kenyataannya di banyak negara, literasi masih menjadi hal yang langka (Wagner, 2015, 2017).

Salah satu literasi yang perlu menjadi perhatian dalam dunia pendidikan adalah literasi sains (Greenhow, Gibbins, \& Menzer, 2015; Klucevsek, 2017; Wu, Zhang, \& Zhuang, 2018). Sains berperan penting sebagai fondasi perkembangan teknologi di dunia ini. Masyarakat yang berliterasi sains akan mampu memahami, menggunakan, bahkan mengembangkan berbagai teknologi sesuai tuntutan perubahan zaman (Snow \& Dibner, 2016). Di lingkup pendidikan dasar, siswa yang berliterasi sains diindikasikan dengan menguasai, memahami, dan memiliki keterampilan membaca, menulis, dan menghitung. Di lingkup pendidikan tinggi, mereka akan memiliki sikap ilmiah, menguasai metode ilmiah, dan memiliki keterampilan proses sains (Anelli, 2011; Dragoş \& Mih, 2015). Berkaitan dengan pentingnya kompetensi ini, pemberdayaan literasi sains para calon penerus bangsa dapat dianggap sebagai penentu pencapaian masa depan yang lebih baik dan berkelanjutan.

Pemberdayaan literasi sains terhadap masyarakat maupun siswa bukanlah usaha yang mudah bagi setiap negara, termasuk di Indonesia. Pemberdayaan literasi sains membutuhkan sumber daya yang berkompeten, sistem pendidikan yang tepat, hingga sarana dan prasarana yang mendukung (Ashri \& Hasanah, 2015; Mcfarlane, 2013; Snow \& Dibner, 2016). Daerah yang kekurangan sumber daya berkompeten maupun sarana dan parasarana yang memprihatinkan berpotensi mengalami kesulitan memberdayakan literasi sains masyarakatnya. Daerah-daerah dengan kondisi semacam ini banyak ditemukan di berbagai provinsi di Indonesia, salah satunya adalah di provinsi Nusa Tenggara Timur (NTT). Salah satu pulau daerah di NTT yang menggambarkan kondisi tersebut adalah di Pulau Kera di Kabupaten Kupang.

Pulau Kera merupakan salah satu dari 550 pulau yang ada di NTT. Pulau yang ditempati kurang lebih 128 Kepala Keluarga ini merupakan bagian dari Desa Uiasa, Kecamatan Semau. Pulau seluas 48,17 hektar ini merupakan wilayah taman wisata Taman Laut Teluk Kupang berdasarkan Surat Keputusan Menteri Kehutanan Nomor 18/KPTS-II/1993 Tanggal 28 Januari 1993 sehingga seharusnya tak ada pemukiman penduduk. Namun faktanya sudah sejak lama pulau kera ditempati nelayan keturunan Suku Bajo, Sulawesi, yang sudah mendiami pulau ini sejak tahun 1900-an (Abdussamad \& Aiman, 2018). Hasil observasi menunjukkan bahwa kondisi pendidikan masih jauh dari harapan karena di Pulau Kera hanya terdapat sebuah sekolah darurat dan seorang tenaga pengajar sukarelawan.

Berdasarkan pada hasil observasi, dapat diketahui bahwa terdapat fasilitas pendidikan di Pulau Kera namun pemanfaatanya sebagai tempat penyelenggara proses belajar mengajar masih belum terlalu maksimal. Alasannya, fasilitas belajar tersebut hanya berupa sekolah darurat. Permasalah lain yang teridentifikasi adalah adanya kesenjangan pengetahuan masyarakat Pulau Kera dengan masyarakat yang tinggal di perkotaan. Minimnya buku pelajaran maupun peralatan sekolah seperti buku tulis, pensil, hingga ballpoin juga mengurangi sumber pengetahuan bagi para siswa. Kondisi tersebut diperparah dengan informasi dari publikasi terdahulu yang melaporkan kurangnya dukungan para orang tua agar anaknya meraih pendidian tinggi. Akibatnya, anak-anak sering kehilangan motivasi untuk belajar (Abdussamad \& Aiman, 2018). Orangtua lebih menggiginkan anaknya membantu mereka untuk mencari nafkah sebagai nelayan, sehingga faktor-faktor inilah yang dapat mempengaruhi rendahnya literasi sains anak-anak usia sekolah dasar.

Berdasarkan dengan kurangnya sarana dan prasarana sebagai fasilitas pendukung dan juga semangat juang anak usia sekolah untuk melanjutkan studi yang sering melemah, maka perlu adanya inovasi dari lembaga pendidikan lainnya sehingga dapat memberikan motivasi kepada siswa di pulau kera untuk terus berusaha melanjutkan pendidikannya. Oleh karena itu, tujuan program pengabdian kepada masyarakat ini adalah untuk mendampingi kegiatan pemberdayaan literasi sains di Pulau Kera. Kegiatan pengabdian ini diharapkan mampu membentuk pola pikir, perilaku, dan membangun karakter serta motivasi agar anak usia sekolah serta orangtuanya peduli serta bertanggung jawab terhadap dirinya agar bisa menggapai masa depan yang cerah.

Lebih lanjut, tujuan penulisan artikel ini adalah untuk memberikan gambaran proses pengimplementasian kegiatan pengbadian yang mampu memberikan kontribusi pada pembentukan masyarakat dengan memiliki daya saing di era Abad 21. Informasi semacam ini merupajan informasi penting yang dapat dijadikan dasar program pengbadian serupa. Selain itu, keberadaan artikel ini juga akan berkontribusi dalam menggairahkan program pengabdian yang sejalan. Program pengbadian yang berfokus pada literasi sains dianggap urgen digalakkan karena berkontribusi dalam pencapaian Sustainable Development Goals (SDGs). Pemecahan berbagai permasalahan yang tertuang di 17 goals tidak terlepas dari penguasaan sains masyarakat (Marope, 2017; Queiruga-Dios, López-Iñesta, Diez-Ojeda, Sáiz-Manzanares, \& Dorrío, 2020). Tak heran, dengan pemberdayaan literasi sains dari sekolah dasar hinggi perguruan tinggi akan berkontribusi besar dalam pencapaian 17 tujuan yang dirumuskan dalam kerangka SDGs.

\section{METODE}

Kegiatan pengabdian ini dilaksanakan di Pulau Kera, Kabupaten Kupang, Provinsi NTT. Kegiatan pengabdian melibatkan dosen Program Studi PGSD FKIP Universitas Muhammadiyah Kupang yang dibantu oleh mahasiswa Himapro 
PGSD. Di lokasi, kegiatan pengabdian melibatkan siswa sekolah darurat, guru sukarela, dan warga Suku Bajo yang mendiami pulau tersebut.

Metode pelaksanaan yang digunakan dalam program PKM ini mengacu pada Uslan, Sunimbar, Ahmad, Abdussamad, dan Musa (2019) yang dibagi menjadi beberapa tahapan. Pertama, tahap persiapan melalui rapat koordinasi tim pelaksana kegiatan pengabdian serta penentuan jadwal untuk menjalin kerjasama dengan masyarakat Pulau Kera Kabupaten Kupang. Tahapan ini bertujuan untuk mendapatkan izin pelaksanaan pengabdian di Pulau Kera. Kedua, melakukan pemetaan masalah agar kegiatan yang dilakukan tepat sasaran. Permasalahan mendasar yang diidentifikasi melalui tahapan ini adalah banyaknya siswa yang kurang melek baca dan tulis karena kurangnya fasilitas pendukung seperti buku referensi serta perlengkapan sekolah. Ketiga, sosialisasi kegiatan kepada masyarakat yang mendiami pulau tersebut. (4) Penyelenggaraan kegiatan pendampingan pemberdayaan literasi sains kepada siswa sekolah darurat yang berlangsung selama dua hari di Bulan Desember 2019. Kegiatan tersebut meliputi pembagian buku bacaan dan perlengkapan sekolah serta mendampingi siswa dalam kegiatan peningkatan literasi sains. Untuk mendukung gerakan literasi disekolah darurat, pembuatan media pembelajaran yang edukatif dengan memanfaatkan limbah plastik juga dilakukan. Pembuatan pojok baca yang dilengkapi dengan buku-buku bacaan yang menarik untuk menambah referensi anak-anak dan orang tua tentang dunia luar turut disediakan. Selain itu, pemberian hadiah juga dilakukan untuk anakanak berupa pemberian buku pelajaran, buku tulis dan perlengkapan sekolah. Kelima, kegiatan observasi dan evaluasi. Sejalan dengan Dalle (2017), tahapan ini bertujuan untuk mengetahui tingkat pemahaman siswa setelah diberikan pendampingan literasi sains yang mengacu pada Kementerian Pendidikan dan Kebudayaan tahun 2016 yang meliputi tahapan pembiasaan, pengembangan, dan pembelajaran

Indikator keberhasilan siswa adalah dengan memberikan angket respon terhadap materi yang telah disampaikan. Angket tersebut mengeksplorasi literasi dalam pembelajaran dengan menggunakan skala Likert. Selain itu, instrumen tes juga digunakan untuk proses pengumpulan data. Merujuk pada Aiman dan Ahmad (2020), tes dilakukan sebanyak dua kali, yaitu sebelum dan sesudah kegiatan.

\section{HASIL dan PEMBAHASAN}

Tim PKM Prodi PGSD Universitas Muhammadiyah Kupang telah melakukan kegiatan literasi sains di Pulau Kera selama 2 hari. Sebanyak 50 anak-anak terdata sebagai muri di sekolah darurat di pulau tersebut. Tim mendapati hanya kurang dari 50\% siswa usia sekolah yang menguasai literasi dasar (membaca, tulis, dan hitung). Sisanya mampu menulis namun tidak bisa membaca, bisa membaca namun tidak memahami apa yang dibaca, bahkan ada yang belum tau berhitung sama sekali. Angka ini didapat ketika mahasiswa memberikan soal latihan untuk mengetahui kemampuan membaca, menulis, dan berhitung. Hal ini terjadi karena belum tersedianya tenaga pendidik yang mencukupi. Tercatat, hanya terdapat 1 orang guru sukarela yang ada di Pulau Kera. Selain itu, sarana pendidikan yang belum memadai memperparah penyelenggaraan proses pendidikan di pulau tersebut.

Berbagai kegiatan diselenggarakan dengan harapan dapat memberikan semangat bagi mereka untuk lebih giat dan rajin bersekolah serta dapat meningkatkan prestasi belajar mereka. Salah satu kegiatan yang dilakukan adalah dengan menyediakan media pembelajaran yang mendukung pemberdayaan literasi sains. Dokumentasi kegiatan pengabdian ini disajikan di Gambar 1. Pembuatan media pembelajaran dilakukan agar kegiatan literasi sains yang dikembangkan dapat berjalan lebih optimal. Keberadaan aktivitas belajar dengan memanfaatkan limbah serta membuat pojok baca bisa diharapkan agar peserta usia sekolah (anak-anak) yang mendiami Pulau Kera dapat mengetahui lingkungan sekitar. Kegiatan ini juga dapat membantu mereka untuk memahami buku bacaan melalui media yang disiapkan dan juga membuka wawasan anak-anak supaya menyerap ilmu pengetahuan sehingga tidak tertinggal jauh dengan anak sebayanya yang hidup diwilayah perkotaan. Dengan kegiatan ini juga melatih mahasiswa calon guru yang terlibat dalam program pengabdian untuk mengaplikasikan pengetahuan yang telah mereka pelajari di bangku kuliah, serta menumbuhkan rasa peka terhadap lingkungan sekitar sebagaimana menurut Wibawanti (2013).

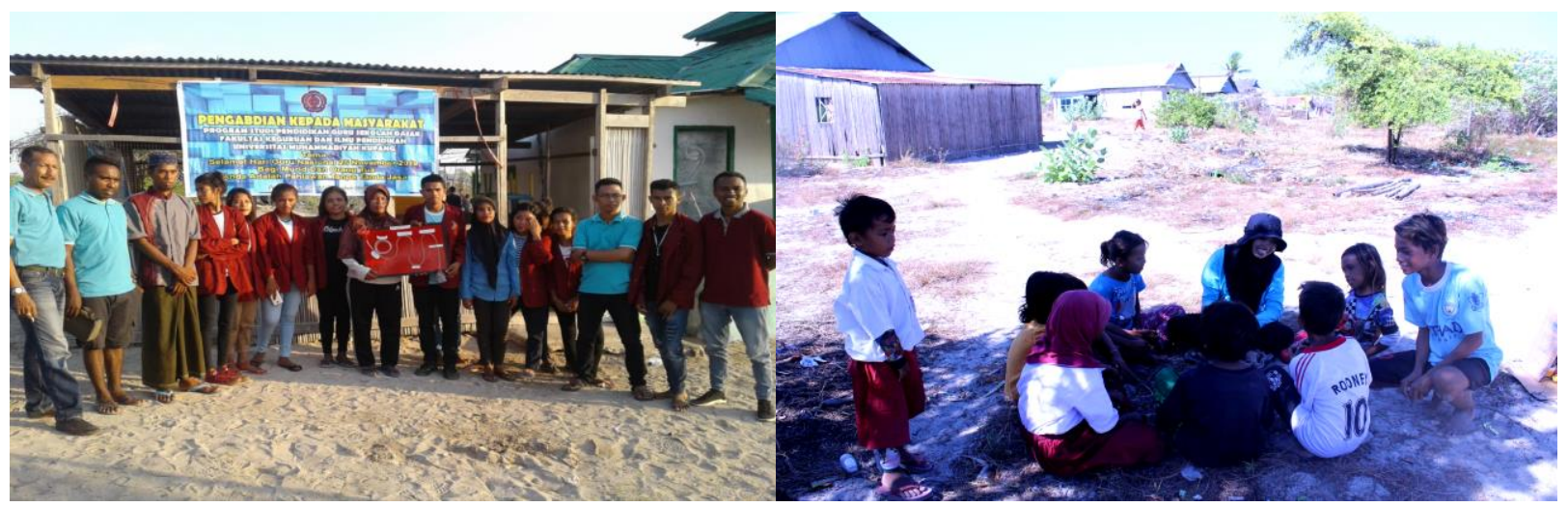

Gambar 1. Aksi mahasiswa Prodi PGSD UM Kupang dalam membuat media pembelajaran 
Permainan edukasi dan aksi untuk alam sekitar juga dilakukan selama pelaksanaan pengabdian. Metode pembelajaran ini dilakukan agar anak-anak tidak merasa bosan (Stasieńko, 2014) serta mengoptimalkan proses pembelajaran (Liu \& Chen, 2013; Varzani, 2013). Pembelajaran ini juga dapat mengajarkan mereka untuk lebih mencintai alam dan lingkungan sekitar. Dengan pembelajaran yang diarahkan secara kontekstual semacam ini juga akan mendorong terciptanya pembelajaran yang bermakna.Selain itu, proses pembelajaran yang diimplementasikan di kegiatan pengabdian ini diupayakan disajikan dengan menyenangkan. Jika sekolah berjibaku dengan teks tetapi miskin percobaan, anak-anak semakin takut dengan bayangan sains yang rumit dan menakutkan apalagi disekolah darurat yang minim sarana dan prasarana (Habibullah, 2020). Untuk itu perlu adanya suatu kegiatan yang dapat menyederhanakan sains, menjadikan sains dengan penuh kegembiraan.

Kegiatan selanjutnya ditunjukkan pada Gambar 2 adalah kegiatan membagi perlengkapan sekolah berupa alat tulis dan bahan bacaan. Sebagai jendela ilmu, membaca merupakan kunci untuk mengakses segala ilmu pengetahuan. Oleh karena itu diperlukan membuka wawasan anak-anak usia sekolah dengan membaca. Sebanyak 50 buku bacaan, buku dan alat tulis menulis, majalah anak, komik, serta bacaan-bacaan edukasi untuk menambah wawasan anak-anak diserahkan dalam suasana kekeluargaan yang bertempat di sekolah darurat yang berada di Pulau Kera. Dalam menyiapkan perlengkapan ini tentu Program Studi tidak bergerak sendiri dengan dukungan dari HIMAPRO PGSD akhirnya terkumpul sejumlah perlengkapan sekolah dan buku bacaan.
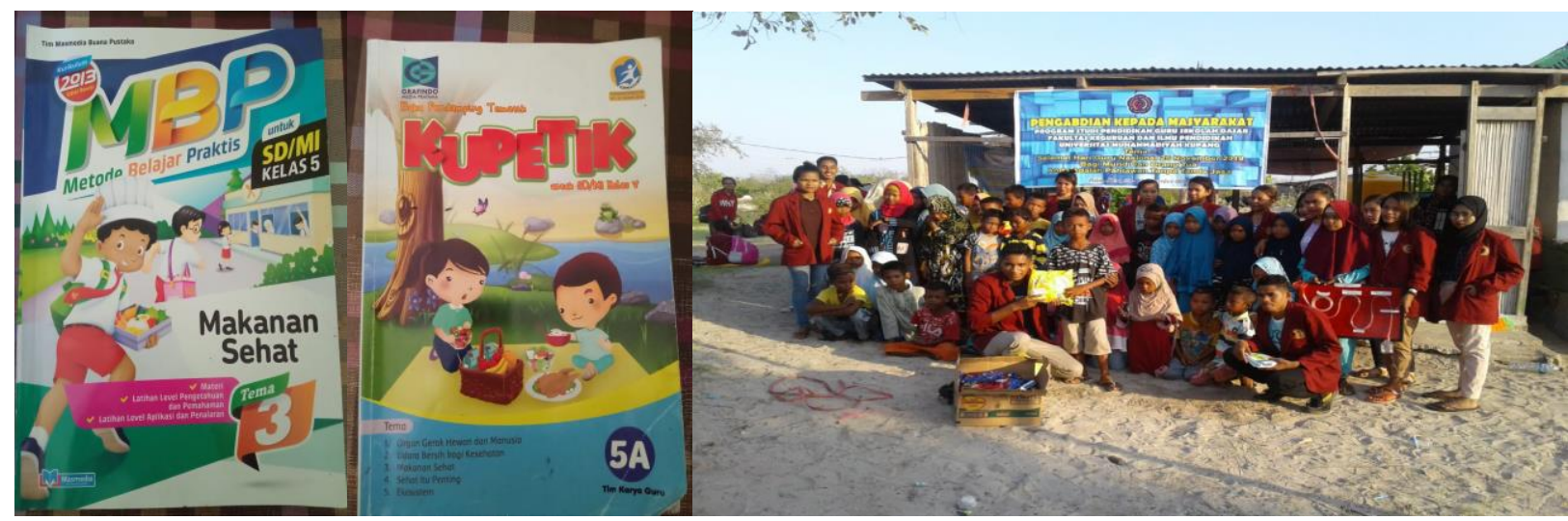

Gambar 2. Penyerahan perlengkapan sekolah dan bahan bacaan

Kegiatan yang paling diminati siswa dalam rangkaian kegiatan literasi sains di pulau kera adalah permainan edukasi (Gambar 3). Mahasiswa yang didampingi oleh dosen mengajak anak-anak bermain sambil belajar. Permainan Edukasi merupakan metode pembelajaran yang dikemas dalam permainan-permainan yang menarik sehingga anak-anak dapat belajar sambil bermain tanpa rasa bosan. Mahasiswa melatih anak-anak untuk membuat pohon cita-cita, melatih anakanak untuk baca, tulis, hitung dan permainan edukatif lainnya. Mahasiswa mendapatkan pengalaman baru nyatanya melalui kegiatan bermain, ternyata juga mengandung praktikum mini sains. Kegiatan praktikum-praktikum yang selama ini didapatkan dibangku kuliah, digubah menjadi contoh bermain yang menyenangkan untuk anak-anak.Dengan cara ini diharapkan anak-anak akan bisa termotivasi minat sainnya hanya dari kegiatan bermain, bukan berpikir formal saintifik. Anak-anak bisa bergembira tetapi langsung diperkenalkan dunia sains dengan penuh kegembiraan. Menurut Idrus (2018), kegembiraan anak ketika proses pembelajaran akan menumbuhkan rasa suka mereka terhadap sains Oleh karena itu, pendekatan bermain menjadi sangat relevan agar anak-anak mencintai sesuatu apalagi di daerah yang minim sarana dan prasarana pembelajaran seperti di Pulau Kera.

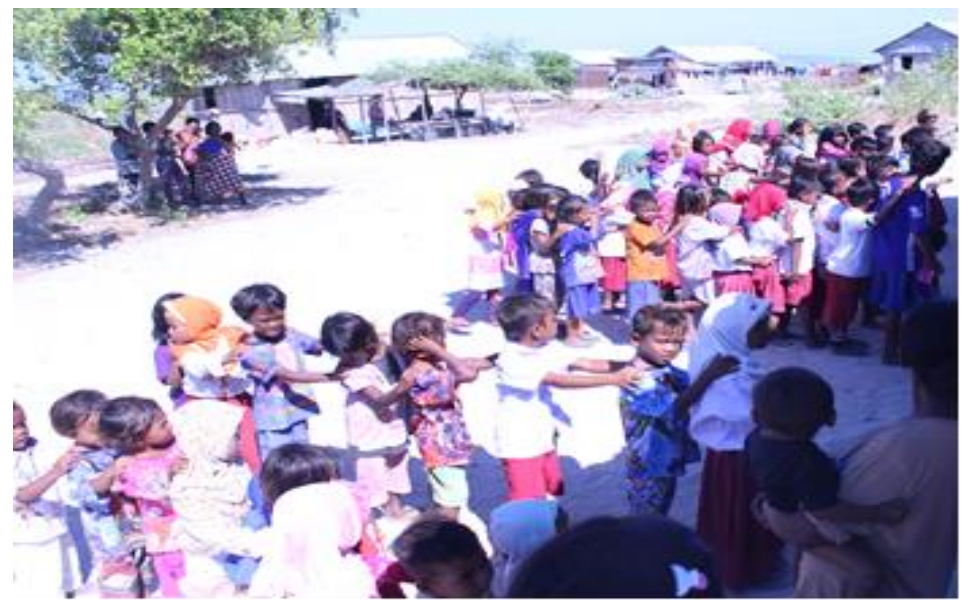

Gambar 3. Permainan edukasi 
Pemanfaatkan lingkungan sekitar sebagai sumber belajar sebagai sumber belajar merupakan salah satu cara yang dapat dilakukan oleh pendidik untuk menerapkan literasi sains dalam pembelajaran (Chanapimuk, Sawangmek, \& Nangngam, 2018; Kristyowati \& Purwanto, 2019). Dengan memanfaatkan keadaan alam yang sesuai dengan kehidupannya sehari-hari, peserta didik bisa diajak untuk melakukan pengamatan dan kegiatan ilmiah sederhana karena peserta didik dapat berinteraksi langsung serta memanfaatkan lingkungan sebagai sumber belajar. Melalui pembelajaran dan pengamatan sederhana langsung di alam, tujuan dari pembelajaran literasi sains dapat diserap secara sempurna untuk menjelaskan fenomena ilmiah dan mengambil kesimpulan berdasarkan apa yang mereka amati secara langsung (Aiman, Uslan, \& Nuriyah, 2018; Anelli, 2011).

Lebih lanjut, implementasi pembelajaran sains harus menekankan aspek kontekstual dan berbasis pada permasalahanpermasalahan yang berkaitan dengan kehidupan sehari-hari (Anelli, 2011; Wibawa, Ratnadi, \& Affandi, 2020). Didasarkan pada berbagai informasi tersebut, pendekatan serta model yang tepat harus diterapkan agar anak-anak di Pulau tersebut tidak buta aksara serta mampu mendorong mereka menggapai cita-cita seperti anak Indonesia lainnya di wilayah perkotaan. Oleh sebab itu kegiatan ini sangat bermanfaat karena dapat menumbuhkan minat siswa dalam hal membaca, menulis dan berhitung. Kegiatan ini juga sangat tepat sasaran karena daerah tersebut benar-benar berada di daerah tertinggal, dan benar-benar membutuhkan kegiatan seperti yang kami lakukan.

\section{KESIMPULAN}

Berdasarkan hasil dan pembahasan terhadap kegiatan literasi sains bagi siswa sekolah dasar di Pulau Kera disimpulkan secara umum kegitan literasi yang dilakukan Program Studi PGSD Universitas Muhammadiyah Kupang berjalan dengan efektif. Kegiatan ini sangat bermanfaat bagi anak-anak usia sekolah walaupun mereka berada di sekolah darurat mereka tetap antusias dan memiliki kemauan sehingga mau berusaha untuk belajar literasi dasar (calistung). Peserta didik bergembira karena mendapatkan pengalaman baru seperti permainan edukasi, hadiah berupa perlengkapan sekolah. Untuk saran perlu adanya kerjasama dengan pemerintah untuk mengatasi permasalahan pendidikan terutama yang berhubungan dengan sarana prasarana dan tenaga pengajar professional yang mendukung aktifitas belajar mengajar agar lebih efektif. Selain itu perlunya peran aktif dari berbagai stakeholder dalam meningkatkan literasi sains siswa di pulau-pulau terluar seperti pulau kera yang berada di Kabupaten Kupang Nusa Tenggara Timur.

\section{UCAPAN TERIMA KASIH}

Terima kasih kepada Ketua LP3M dan Dekan Fakultas Keguruan dan Ilmu Pendidikan Universitas Muhammadiyah Kupang, masyarakat Pulau Kera beserta HIMAPRO PGSD atas dukungannya sehingga kegiatan PKM ini dapat berjalan sesuai yang diharapkan.

\section{REFERENSI}

Abdussamad, Z., \& Aiman, U. (2018). The Kera Island calls: Developing literacy at emergency school In The Kera Island, Kupang, East Nusa Tenggara. Proceeding of International Conference: Primary Education Pivotal Literature and Research UNNES, 104-108. Semarang: Jurusan Pendidikan Guru Sekolah Dasar (PGSD)FIP UNNES.

Aiman, U., \& Ahmad, R. A. R. (2020). Model Pembelajaran Berbasis Masalah (PBL) terhadap literasi sains siswa kelas V Sekolah Dasar. Jurnal Pendidikan Dasar Flobamorata, 1(1), 1-5.

Aiman, U., Uslan, U., \& Nuriyah, N. (2018). Improvement of jas-based learning outcomes in the plant material and its life in PGSD products, Muhammadiyah University, Kupang. Rogressive and Fun Education (Profunedu) International Conference Proceeding, (August), 313-318.

Anelli, C. (2011). Scientific literacy: What is it, are we teaching it,and does it matter? American Entomologist, 57(4), 235-244. https://doi.org/10.1093/ae/57.4.235

Ashri, N., \& Hasanah, L. (2015). Pengembangan bahan ajar IPA terpadu pada tema energi dan lingkungan. Simposium Nasional Inovasi Dan Pembelajaran Sains.

Budiyanto, M. A. K., \& Hadi, S. (2020). Science and technology for the community of traditional beef cattle farmers who face animal feed problem. Journal of Community Service and Empowerment, 1(1), 37-45. https://doi.org/10.22219/jcse.v1i1.11511

Bybee, R., \& McCrae, B. (2011). Scientific literacy and student attitudes: Perspectives from PISA 2006 science. International Journal of Science Education, 33(1), 7-26. https://doi.org/10.1080/09500693.2011.518644

Çalışkan, H. K. (2015). Technological change and economic growth. Procedia-Social and Behavioral Sciences, 195, 649654. https://doi.org/10.1016/j.sbspro.2015.06.174

Chanapimuk, K., Sawangmek, S., \& Nangngam, P. (2018). Using Science, Technology, Society, and Environment (STSE) approach to improve the scientific literacy of grade 11 students in Plant Growth and Development. Journal of Science Learning, 2(1), 14-20. https://doi.org/10.17509/jsl.v2i1.11997

Christy, B., \& Duane, D. (2013). The role of innovation education in student learning, economic development, and university engagement. The Journal of Technology Studies, 39(2), 102-111. 
https://doi.org/10.21061/jots.v39i2.a.4

Dalle, A. (2017). Penerapan gerakan literasi di Sekolah Menengah Pertama Neqeri 4 Pare-pare. UIN Alauddin Makasar.

Dragoş, V., \& Mih, V. (2015). Scientific literacy in school. Procedia-Social and Behavioral Sciences, 209(July), 167-172. https://doi.org/10.1016/j.sbspro.2015.11.273

GPE Secretariat. (2019). Literacy is key to achieving the SDGs by 2030. Retrieved April 14, 2020, from Global Partnership for Education website: https://www.globalpartnership.org/blog/literacy-key-achieving-sdgs-2030

Greenhow, C., Gibbins, T., \& Menzer, M. M. (2015). Re-thinking scientific literacy out-of-school: Arguing science issues in a niche Facebook application. Computers in Human Behavior, 53, 593-604.

https://doi.org/10.1016/j.chb.2015.06.031

Habibullah, A. (2020). Anak muda hebat Indonesia: Be The Boss in your own life. Medan: Gerhana Publishing.

Idrus, E. (2018). Membongkar psikologi belajar aplikatif. Guepedia.

Jeronen, E., Palmberg, I., \& Yli-Panula, E. (2016). Teaching methods in biology education and sustainability education including outdoor education for promoting sustainability-A literature review. Education Sciences, 7(1), 1-19. https://doi.org/10.3390/educsci7010001

Kaur, M. (2013). Blended learning - Its challenges and future. Procedia-Social and Behavioral Sciences, 93, 612-617. https://doi.org/10.1016/j.sbspro.2013.09.248

Klucevsek, K. (2017). The intersection of information and science literacy. Communications in Information Literacy, 11(2), 354-365. https://doi.org/10.15760/comminfolit.2017.11.2.7

Kristyowati, R., \& Purwanto, A. (2019). Pembelajaran literasi sains melalui pemanfaatan lingkungan. Scholaria: Jurnal Pendidikan Dan Kebudayaan, 9(2), 183-191. https://doi.org/10.24246/j.js.2019.v9.i2.p183-191

Lin, Y.-S. (2011). Fostering creativity through education - A conceptual framework of creative pedagogy. Creative Education, 02(03), 149-155. https://doi.org/10.4236/ce.2011.23021

Liu, E. Z. F., \& Chen, P.-K. (2013). The effect of game-based learning on students' learning performance in science learning - A case of "Conveyance Go." Procedia - Social and Behavioral Sciences, 103, 1044-1051. https://doi.org/10.1016/j.sbspro.2013.10.430

Marope, P. T. M. (2017). Literacy: A foundation for achieving the Sustainable Development Goals. Prospects, 47(3), 163165. https://doi.org/10.1007/s11125-018-9436-y

Mashfufah, A., Nurkamto, J., Sajidan, \& Wiranto. (2018). Environmental literacy among biology pre-service teachers: A pilot study. AIP Conference Proceedings. https://doi.org/10.1063/1.5054444

Mcfarlane, D. A. (2013). Understanding the challenges of science education in the 21st century: New opportunities for scientific literacy. International Letters of Social and Humanistic Sciences, 4, 35-44. https://doi.org/10.18052/www.scipress.com/ILSHS.4.35

Montoya, S. (2018). Meet the SDG 4 data: Measuring youth and adult literacy and numeracy. Retrieved April 14, 2020, from Global Partnership for Education website: https://sdg.uis.unesco.org/2018/08/29/meet-the-sdg-4-datameasuring-youth-and-adult-literacy-and-numeracy/

Nurwidodo, N., Amin, M., Ibrohim, I., \& Sueb, S. (2020). The role of eco-school program (Adiwiyata) towards environmental literacy of high school students. European Journal of Educational Research, 9(3), 1089-1103. https://doi.org/10.12973/eu-jer.9.3.1089

Palani, K. K. (2012). Promoting reading habits and creating literate society. Journal of Arts, Science \& Commerce, 3(2), 90-94.

Purnama, R., \& Apriliani, A. (2018). Pengentasan kemiskinan di Desa Talok melalui pendidikan non formal berbasis anyaman bambu dengan metode pembangunan berkelanjutan pasal 7 UU No. 13 Tahun 2011 menuju sustainable development goals (SDGs) di Indonesia 2045. Lex Scientia Law Review, 2(1), 31-46. Retrieved from https://journal.unnes.ac.id/sju/index.php/Islr/article/download/23641/11024/

Queiruga-Dios, M. Á., López-Iñesta, E., Diez-Ojeda, M., Sáiz-Manzanares, M. C., \& Dorrío, J. B. V. (2020). Citizen science for scientific literacy and the attainment of sustainable development goals in formal education. Sustainability (Switzerland), 12(10), 1-18. https://doi.org/10.3390/su12104283

Scott, C. L. (2015). The futures of learning 2: What kind of learning for the 21st century? In Education Research and Foresight. Paris.

Şener, S., \& Saridoğan, E. (2011). The effects of science-technology-innovation on competitiveness and economic growth. Procedia - Social and Behavioral Sciences, 24, 815-828. https://doi.org/10.1016/j.sbspro.2011.09.127

Snow, C. E., \& Dibner, K. A. (2016). Science literacy: Concepts, contexts, and consequences. In Science Literacy: Concepts, Contexts, and Consequences. https://doi.org/10.17226/23595

Stasieńko, J. (2014). 'Why are they so boring?' - educational context of computer games in design and research perspectives. Neodidagmata, 35, 47-64. https://doi.org/10.14746/nd.2013.35.4

Suswati, I., \& Maulida, A. P. (2020). Handwashing promotion and the use of hand sanitizer as a preventative measure on the development of bacteria. Journal of Community Service and Empowerment, 1(1), 31-36. https://doi.org/10.22219/jcse.v1i1.11510

Uslan, U., Sunimbar, S., Ahmad, A., Abdussamad, Z., \& Musa, M. (2019). Penyuluhan tentang pemanfaatan kulit batang 
tumbuhan faloak (Sterculia Quadrifida R. Br) di Kelurahan Kayu Putih Kota Kupang. Prosiding Seminar Nasional Hasil Penelitian LPPM Universitas PGRI Madiun, 347-351. Madiun: Universitas PGRI Madiun.

Varzani, M. R. (2013). A study of the role of games in the learning improvement of elementary schoolboys in Karaj, Iran. Procedia - Social and Behavioral Sciences, 84, 400-404. https://doi.org/10.1016/j.sbspro.2013.06.574

Wagner, D. A. (2015). Is literacy the key to achieving the SDGs. Retrieved April 14, 2020, from World Economic Forum website: https://www.weforum.org/agenda/2015/10/is-literacy-the-key-to-achieving-the-sdgs/

Wagner, D. A. (2017). Learning, literacy and sustainable development: Inclusion, vulnerability, and the SDGs. In Children and Sustainable Development: A Challenge for Education. https://doi.org/10.1007/978-3-319-47130-3

Wibawa, M. A. N., Ratnadi, R., \& Affandi, L. H. (2020). Pengaruh model pembelajaran Children Learning In Science (Clis) terhadap pemahaman konsep IPA Siswa Kelas III SD Negeri Gugus I Sandubaya Tahun Ajaran 2019/2020. Progres Pendidikan, 1(1), 1-6.

Wibawanti, D. (2013). Persepsi dan perilaku mahasiswa dalam pendidikan karakter. Surakarta.

Wu, S., Zhang, Y., \& Zhuang, Z. Y. (2018). A systematic initial study of civic scientific literacy in China: Cross-national comparable results from scientific cognition to sustainable literacy. Sustainability (Switzerland), 10(9). https://doi.org/10.3390/su10093129 